versenyfeltételének elengedhetetlen alapja a szervezeti tudás minél jobb fel- és kihasználása. Ez a tudás azonban a szervezet sajátos humántóke-specifikusságában tükröződik, amely ma egyre inkább a posztindusztriális foglalkoztatási modellbe ágyazódik. Innen válik Klein Balázs és Klein Sándor munkája érdekessé, mert tudományos színvonalon, harminc éve a munka világában eredményesen alkalmazott pszichológiai eszközrendszert sứít egybe azért, hogy a szervezetben múködó személyiség egyénileg és közösségében is sikeres lehessen. A rendszerelvúen összeállított kötet fô célja, hogy az emberi erôforrással kapcsolatos különféle tudományok módszertani kérdéseiból és tipi kus megoldásra váró problémáiról általános következtetéseket vonjon le. Ezekból pedig - a gazdag esettanulmányokkal bizonyitva - a sikeres eljárásokat tudatosítsa. A hazai emberi eróforrás-szakirodalomban A szervezet lelke kötet pszichológiai akciókutatásokkal kimunkált ismeretrendszere és szemléletmódja azt vallja, hogy a tudomány eredményeinek, illetve a tudományok múvelése során született eredményeknek a szervezet gyakorlatába történố beültetésével az emberi erôforrás minőségi múködése valósulhat meg. A változó piacgazdaság eseményei között legalább az emberról tudjunk még több valóságost - ezt szolgálja A szervezet lelke, ezzel segítve azt, hogy a szervezetek emberitóke állományuk növekvő részét is egyre inkább a portfólióbefektetések kezeléséhez hasonló rugalmassággal irányítsák.

Dr. Krisztián Béla

\section{PATAKI Béla A TECHNOLÓGIA MENEDZSELÉSE}

Gyorsuló Tudomány, Typotex, Budapest, 20o5. 207 p.

A tudomány gyorsuló fejlódése a tudományos könyvkiadást is új kihívások elé állítja. Ennek jegyében született a „Gyorsuló tudomány sorozat”, melynek indításával a kiadó bepillantást kíván nyújtani az olvasónak a tudomány egy-egy szeletébe. A sorozat elsố kötetét tarthatja kezében az érdeklődő, Pataki Béla, a Budapesti Múszaki és Gazdaságtudományi Egyetem docensének könyvét. A tudásalapú társadalomban és gazdaságban a technológiamenedzsmentnek kulcsszerepe van a vállalatok sikeres múködésében. A szerző öt fejezetben fejti ki mondanivalóját. A elsóben a technológiamenedzsment alapfogalmát, a technológiák típusait, a menedzsment fogalmát, a technológiamenedzsment fogalmát és szerepét, továbbá a technológiamenedzs- ment kialakulását mutatja be. Pataki Béla a következő meghatározását adja a hazai gyakorlatban némelykor zavarosan értelmezett menedzsmentfogalomnak: emberi, fizikai, pénzügyi és információs erőforrások tervezése, szervezése, irányítása és vezetése a szervezet céljainak eredményes és hatékony kitűzése és elérése érdekében. Fontos megállapítás, hogy nemzetközi példák tanúsága szerint nem finanszírozási vagy marketing, hanem technológiai és a mögöttük meghúzódó technológiamenedzselési fogyatékosságok vezetnek a legtöbb esetben üzemek megszúnéséhez. E felismerésból született a technológiamenedzsment koncepiója.

A könyv második fejezete a technológiai életciklusokat, egyebek közt a technológiai életciklus-görbéket, a technológiák differenciálódását, valamint a menedzseri tévhiteket vázolja az új techológiákról. Több évtizedes megfigyelések alapján kilenc tévhitet sorol fel a szerző, melyek a menedzserek fejében élnek, ilyen például: a technológiai előrelépések vagy felfedezések végül rendszerint sikeresen terjednek el. A valóságban: a legtöbb nem válik sikeressé. A következô, harmadik fejezetben az információtechnológia menedzseléséról esik szó: A vállalat IT vagyona, Mennyire általános ez a gondolkodásmód? A felsô szintû́ menedzsmentre tartozó IT döntések, Lehet-e stratégiai versenyelóny forrása az IT? tagolásban. A vállalati versenyképesség alapja: IT - humánerőforrás, technológiai bázis, erôs partneri kapcsolat az IT és a vállalat menedzsmentje között. Ebben a fejezetben foglalkozik Pataki Béla azzal a vitával, amelyet Nicolas G. Carr Harvard Business Review-ban megjelent cikke váltott ki az IT-nak a stratégiai versenyelóny megszerzésében játszott szerepéról.

A negyedik fejezet a technológia stratégiai jelentôségét, tartalmát, az esetleges típushibákat, portfólióelemzést és a technológiatérképet ismerteti meg az olvasóval. A technológiatérkép kulcsfontosságú technológiamenedzsment eszköz, amely képessé teszi a vállalatot, hogy összekapcsolja technológiai képességeit termékeivel és üzleti terveivel, úgy hogy a stratégia és a technológia fejlesztése együtt haladjon. A könyv befejező fejezetében a magkompetencia-menedzsment témakörében elméletról, vitákról, teendőkról olvashatunk. A könyvet hasznos függelék és irodalomjegyzék zárja, amely a téma szakirodalmáról ad részletesebb tájékoztatást.

Pataki Béla könyve jó bevezetóje lehet egy olyan sorozatnak, amely a tudományos fejlódés egy-egy jelenségét közelebb kívánja hozni mindennapjainkhoz, amely a múszaki és gazdasági folyamatokat egységben, egymásra való kölcsönhatásában mutatja be. Várjuk a folytatást.

Becsky Róbert 